\title{
【特＼cjkstart集：トレーサビリティと電子マニフェスト】
}

\section{国際資源循環におけるトレーサビリティ確保に向けた 第三者認証機関の取り組みと今後の課題}

\author{
松 岡 浩 史 *
}

【要 旨】循環資源は潜在的な污染性を抱えており, リサイクルを名目とした廃書物の輸出, 輸出先国 での環境污染といった問題が発覚している。循環資源の潜在的な污染性をコントロールし, 適正な国際 資源循環を実現するためのツールとして, トレーサビリティ管理の重要性が指摘されてれり，これまで 国や学識経験者，民間事業者などでトレーサビリティ管理の方法などの検討が行われてきた。その成果 として，2009年 3 月に「一般社団法人資源循環ネットワーク」が誕生し，国際資源循環におけるト レーサビリティ確保に向けた第三者認証機関としての活動が開始されている。

本論文では, 一般社団法人資源循環ネットワークの設立経緯, トレーサビリティ確保に向けた取り組 みの現状について紹介するとともに, 国際資源循環におけるトレーサビリティ確保に向けた第三者認証 機関にとっての今後の課題について整理した。

キーワード：国際資源循環，トレーサビリティ，第三者認証機関

\section{1.はじめに}

中国をはじめとするアジア諸国の経済成長を背景とし た素材価格の高騰などに伴い, 循環資源に対する需要が 急速に高まっている。また, 国内のメーカーやリサイク ル業者などでは, 資源の有効活用や廃棄物処理コスト削 減などの観点から, 国際資源循環が拡大している。その 結果, 鉄くず, 古紙, プラスチックくずなどの循環資源 の輸出量は急速に増加しており, プラスチックくず（廃 プラスチック）の輸出量を例にとってみると, 1998 年 の約 14 万 ton に対して, 2007 年は約 152 万 ton ${ }^{1)}$ と 10 倍以上にも増加している（図 1)。

循環資源のリサイクルは資源有効活用の観点から見れ ば重要な取り組みであるが, 廃棄物由来であることから, 適正な処理やリサイクルがされなければ環境污染を招く という潜在的な污染性を抱えている。リサイクルを名目

原稿受付 2010.6.21

*一般社団法人 資源循環ネットワーク

連絡先: $\overline{7} 808-0024$ 福岡県北九州市若松区浜町 1-18-1

ひびき灘開発株式会社内

E-mail :h.matsuoka@trace-recycle.or.jp
とした廃棄物の輸出, 輸出先国のリサイクル過程におけ る環境の污染といった問題は既に数多く発覚しており ${ }^{2)}$, 2004 年には中国で日本からのプラスチックくずの輸入 が暫定的に停止になるという事態が起こっている。

こうした中, 中国などアジア諸国は輸出事業者に対す る登録制度の新設や国内法規制による厳格な品質基準の 設定など, 循環資源輸出入に関する環境関連規制を強化

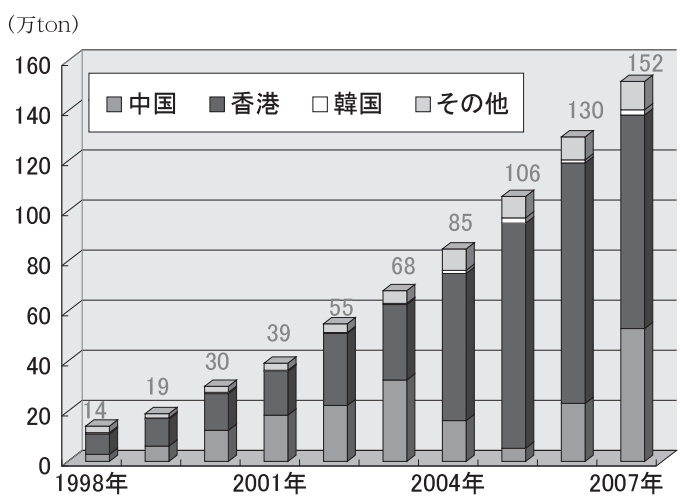

(出典) 財務省貿易統計から作成

図 1 プラスチックくず輸出量の推移 
してきた。しかしながら，これらの規制に対する運用段 階でのチェック体制が必ずしも整備されていないことな どから, 結果的に優良な輸出事業者のビジネス参入機会 が阻害される一方で, 不適正・不法な取引が増加すると いう悪循環にさえ陥っている。この悪循環を断ち切るこ とができなければ，さらに規制が形骸化し，環境問題に ついての潜在的なリスクが拡大していく恐れがある。

\section{2. トレーサビリティ認証機関の設立経緯}

こうした背景を踏まえ, 経済産業省は 2005 年来「持 続可能なアジア循環型経済社会圈構想」3)を掲げ, アジ ア地域全体で資源循環システムを構築することによって, 適正な国際資源循環の実現を目指している。そのツール の一つとしてトレーサビリティ管理の重要性が指摘され ており，2005 年度から 2007 年度において，「二国間に おけるトレーサビリティを確保した資源循環ネットワー クの活用可能性に関する調査事業」が実施された。

同調査事業の過程で, 北九州市と中国天津市との間で 国際資源循環に関する覚え書きが締結され，両市を フィールドとした実証事業が行われた。この結果, ト レーサビリティ管理が循環資源の国際的な取り引きの透 明性を確保し，関係者が自らの社会的責任を果たす上で 有効であるということが実証されるとともに，「二国間 地域連携モデル」（図 2) を基本的な考え方とする「国
際資源循環トレーサビリティガイドライン〜「安全・安 心」な北九州一天津方式〜」が取りまとめられた ${ }^{4)} 。-$ 方, 同調査事業に参加した民間事業者の有志により 2007 年に「資源循環ネットワークコンソーシアム」が 結成され，国際資源循環におけるトレーサビリティの管 理・運営を行う「第三者認証機関」の設立に向け, 具体 的な仕組みや運営方法などについて検討が行われた。

これらの経緯を経て，2009 年 3 月に「一般社団法人 資源循環ネットワーク」（以下，資源循環ネットワーク という $)^{5}$ が誕生し，同年 12 月からトレーサビリティ認 証サービス（以下，認証サービスという）が開始された。 資源循環ネットワークには, 代表理事の諮問機関として 北九州市が事務局を担当する「アドバイザリーボード委 員会」が設置されており, 有識者や行政機関などからの 指導・助言を得ながら, 循環資源の排出事業者に対する 「安全・安心」の提供, 国際資源循環の適正モデルの構 築を目指している。

\section{3. トレーサビリティ認証サービスの概要}

資源循環ネットワークにおける認証サービスの業務フ ローは図 3 に示すとおりである。現在は日本一中国間 における廃プラスチックの国際資源循環を対象として, 排出事業者への認証サービスを提供している。

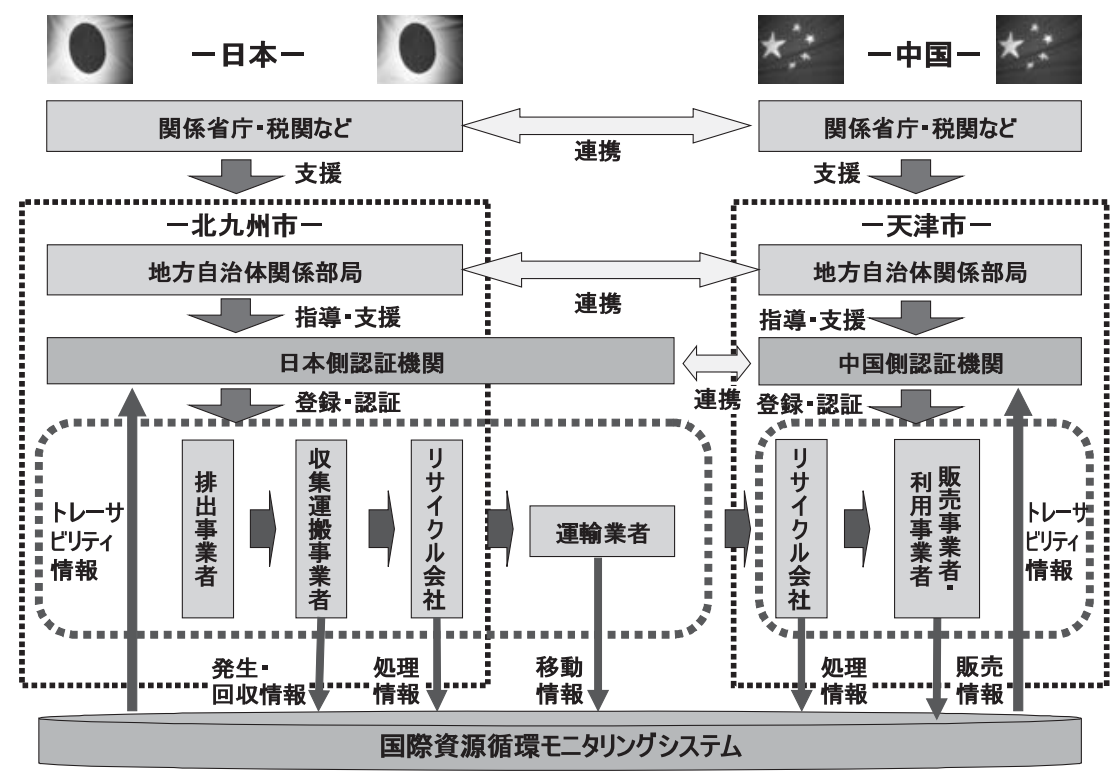

(出典) 資源循環ネットワーク検討委員会資料

図 2 二国間地域連携モデル」のイメージ 


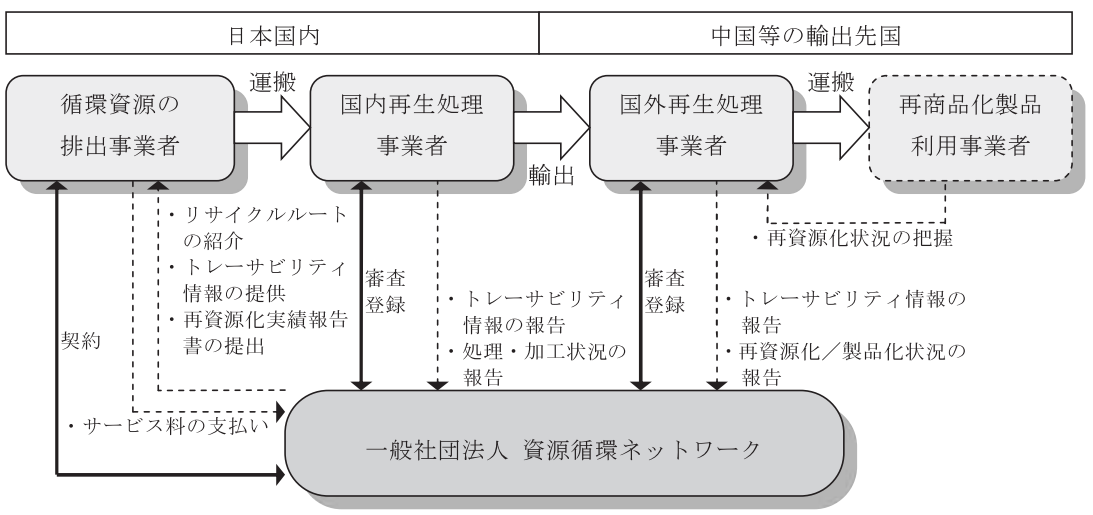

図 3 トレーサビリティ認証サービスの業務フロー

\section{1 適正に資源化を行うリサイクルチェーンの紹介}

適正な国際資源循環を行うためには, 循環資源の排出 段階から再製品化されるプロセス全体を適切な処理・処 分を行うことができるメンバー（リサイクルチェーン） に委ねることが最も重要である。資源循環ネットワーク は, 認証サービスに参加する国内外の再生処理事業者に 係る登録システムを設けている。具体的には, 表 1 に示 すように書類審査と現地審査の二段階審査によって, 適 切に資源化を実施できる設備, トレーサビリティ管理が 可能な運転管理体制を有している事業者のみを登録事業 者として，排出事業者に紹介している（図4）。

\section{2 トレーサビリティ管理による情報の見える化}

国際資源循環におけるトレーサビリティ管理には, 「二国間の関係者にまたがるリサイクルチェーンを通じ た情報管理」と「情報の共有化」が求められる。資源循 環ネットワークは, インターネットを活用することによ り, 循環資源の由来物, 材質, 荷姿, 重量などの入出荷 情報をインターネット上のモニタリングサーバーで管理 し, 排出事業者にトレーサビリティ情報を提供している (図 5)。

また, 再資源化が完了した後, 資源循環ネットワーク が「再資源化実績報告書」を発行し, 排出事業者に対し て適正にリサイクルされたことを証明・報告している。

\section{4. 国際資源循環におけるトレーサビリティ確 保の課題}

資源循環ネットワークが認証サービスを開始して以来, 国内外のフィールドにおいて運用面でのさまざまな課題 に直面してきた。認証サービスの改善を視野に入れ，こ れまでの運用実績を踏まえ, 国際資源循環におけるト
表 1 再生処理事業者登録の審査内容

\begin{tabular}{|l|l|}
\hline \multicolumn{1}{|c|}{ 書類審査 } & \multicolumn{1}{|c|}{ 現地審查 } \\
\hline 許認可取得状況 & インタビュー \\
取引実績 & 施設審査 \\
処理フロー & 管理体制の確認 \\
財務状況 & 取引先の確認 \\
施設の処理能力 等 & 指導・指示 等 \\
\hline
\end{tabular}

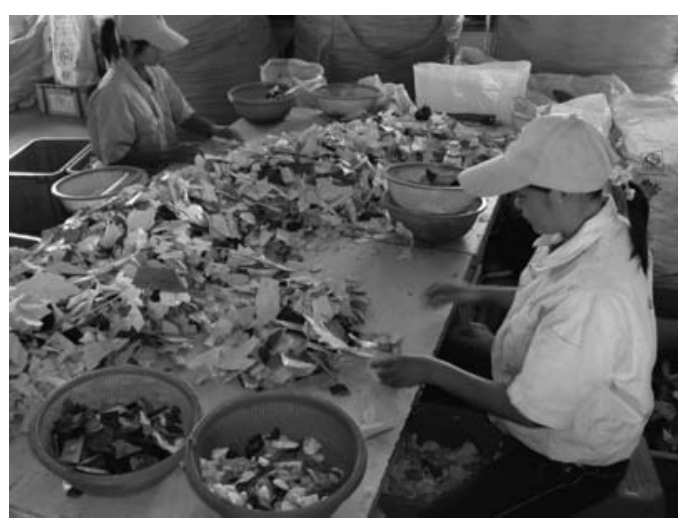

図 4 中国でのリサイクルの様子

レーサビリティ確保に向けた第三者認証機関にとっての 課題を以下に整理した。

\section{1 人為的な管理ミスの防止}

トレーサビリティ情報は, 国際資源循環のプロセスを 排出段階, 国内再生処理段階, 輸出段階, 国外再生処理 段階の 4 つの段階に分け, 各段階の工程内でロット管理 を行った上で，ロットナンバーの紐付けを行うことによ り管理されている。しかしながら, 入力ミスや紐付けミ スにより正確なトレースが実施できなかったケースも発 生した。実務者の人為的な管理ミスをできる限りなくす 


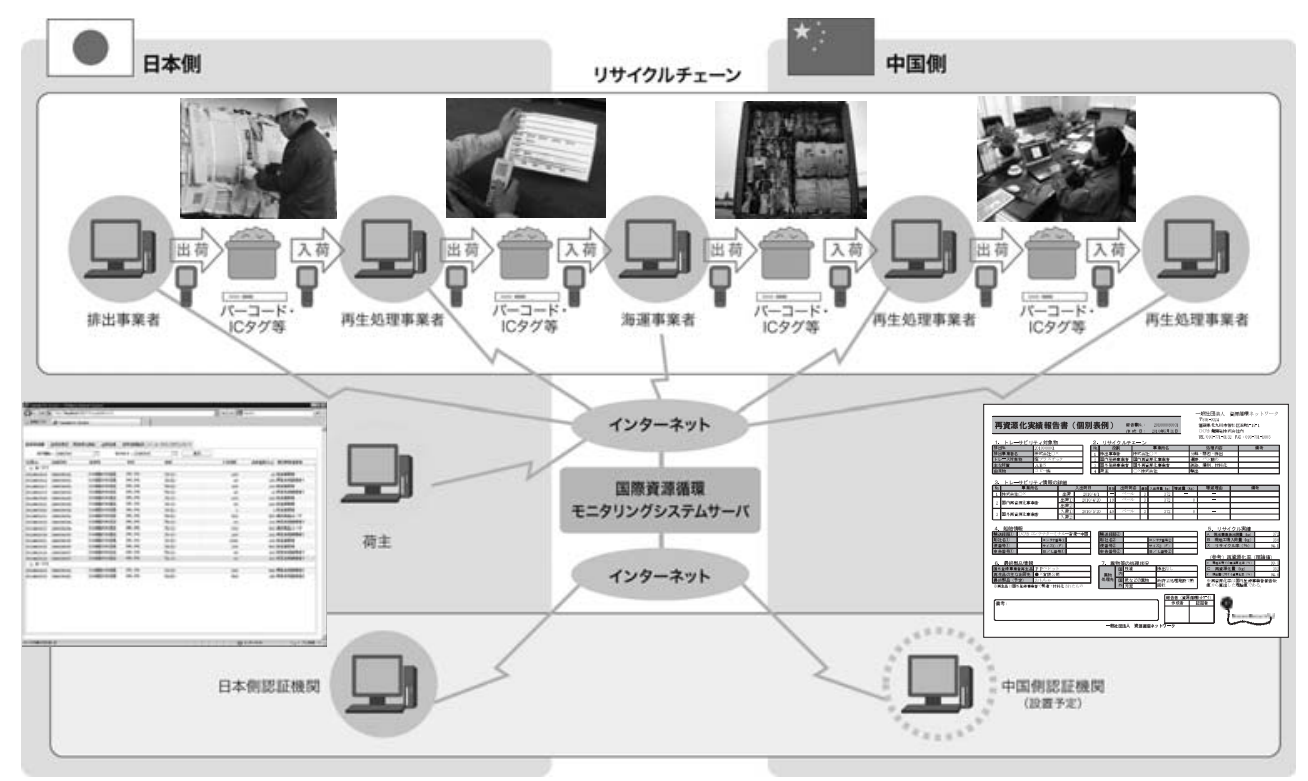

図 5 トレーサビリティ管理のイメージ図

ためには，情報システムの側に入力チェック機能を設け るなどの対策を強化していく必要がある。

\section{2 情報管理機能の高い媒体の導入}

現在の認証サービスでは, コスト低減を図るためバー コードによるトレーサビリティ管理を行っているが, バーコードで認識できる情報の範囲は限られている。今 後さらなるサービスの向上を図るためには, 循環資源の 処理情報や移動経路などを書き込める IC 夕グ, 移動経 路を追跡できるGPS（Global Positioning System）等を 利用して管理することが望ましい。その前提として, 認 証サービスに必要なコストを負担する排出事業者の理解 を得ながら, 追尾可能性の高い IC タグなどの媒体の導 入を図ることが課題となっている。

\section{3 中国における認証機関の整備}

国際資源循環を適正に行うためには，日本・中国のそ れぞれにおいてトレーサビリティ認証機関を設置した上 で，各国の認証機関によって自国のトレーサビリティ管 理を行い, 認証機関の間で情報の共有化を図ることが望 ましい。しかしながら, 現時点では中国側の認証機関は 設置されていない。今後, 中国の関係機関等への働きか けを行うことにより, 資源循環ネットワークのカウン ターパートとなる中国側のトレーサビリティ認証機関の 設置を促していく必要がある。

\section{4 国内外事業者の環境問題意識・社会的な責任意識 の向上}

国際資源循環におけるトレーサビリティ管理を導入し ている国内の排出事業者および再生処理事業者は, 環境 問題意識・社会的な責任意識の高い一部の事業者に限ら れている。また, 多くの中国の再生処理事業者および再 資源利用事業者の間では, 利益優先という考え方が主流 であり，環境問題意識・社会的な責任意識は総じて低い。 環境問題意識・社会的な責任意識の向上については, 国 や関係機関などとも連携を図りながら，技術的・人的な 交流等を通じてねばり強く働きかけていく必要がある。

\section{5. むす び}

国際資源循環を適正化する上で最も重要なことは, 循 環資源が持つ「污染性」というリスクを管理しながら効 率的に「資源性」を抽出することにある。その中で, 資 源循環ネットワークが果たすべき役割は, トレーサビリ ティ認証サービスの提供を通して, 循環資源の排出事業 者のリスクマネジメントを支援するとともに, 国際資源 循環の円滑な取り引きを図っていくことにある。今後は, これまでの活動を通じて具体化してきた課題の解決に着 実に取り組んでいきたい。 
1）財務省貿易統計：

http : //www. customs. go.jp/toukei/info/tsdl.htm

2）小島道一：アジアにおける循環資源貿易, アジア経済

研究所, pp. 49-51 (2005)

3）経済産業省ホームページ：

http : //www.meti.go.jp/policy/recycle/main/3r_ policy/policy/global.html

4) 経済産業省：二国間におけるトレーサビリティを確保 した資源循環ネットワークの活用可能性に関する調査 事業報告書, (株)NTT デー夕経営研究所 (2008)

5 ）(社)資源循環ネットワークホームページ： http : //www. trace-recycle. or.jp/

\title{
A Certifying Institution for Traceability System that Ensures Sound International Resource Circulation : Roles and Problem Solving
}

\author{
Hiroshi Matsuoka \\ Resource Circulation Network Inc. \\ (1-18-1 Hama-Machi, Wakamatsu-ku, Kitakyushu, Fukuoka 808-0024 Japan)
}

\begin{abstract}
The improper handling and trading of recyclable resources has the potential to lead to dispersal of various forms of pollution. The maximum utilization of recyclable resources, on the other hand, has become an urgent issue for Asian countries under present-day resource and environmental constraints.

After intensive discussions held by a group comprised of scholars, local governments and related industries, the Japanese government has concluded establishment of a traceability system that will act as an effective and powerful solution for the control of international resource circulation throughout Asia.

In order to create a new regime for managing international resource circulation in a sound manner, Resource Circulation Network has been founded. This will act as the certifying institution and work based on its own traceability system. RCN has been established as the result of collaboration between both public and private sectors.

This article overviews the background of the Network's foundation and the process in which it was formed. The paper also defines roles and problems to be solved in the active operation of this Network.
\end{abstract}

Keywords : resource circulation, traceability, certifying institution 